\title{
A Better Understanding of Reasons for the Failure of the Healthcare Reform in Colombia
}

\author{
Oscar Bernal, Diana C. Zamora \\ Escuela de Gobierno, Universidad de los Andes, Bogotá, Colombia \\ Email: obernal@uniandes.edu.co
}

Received 29 September 2014; revised 13 November 2014; accepted 30 November 2014

Copyright (C) 2014 by authors and Scientific Research Publishing Inc.

This work is licensed under the Creative Commons Attribution International License (CC BY). http://creativecommons.org/licenses/by/4.0/

(c) (i) Open Access

\section{Abstract}

The Colombian healthcare crisis is evidenced by obstacles to health service, diminished working conditions and medical autonomy, financial infeasibility, loss of leadership and legitimacy of the healthcare system. In the year 2013 twelve reform projects were presented to Congress, including a statutory law that defines health as a fundamental right which was approved and another ordinary one which sought a complete reform of the system but was rejected and criticized by different opinion leaders. For this study we have made an adaptation to $Q$ methodology, which assigns quantitative values to the most frequent statement variables obtained from secondary sources (norms, articles, media, forums) giving objective information about the diverse positions in the proposals to healthcare reform. We analyzed from the most objective position and from academic independence the different views of the opinion leaders for a better understanding of the reasons for this failure in healthcare reform. There was a great polarization in the diverse statements which made an agreement with the government unlikely and, when added to a political moment in which the presidential election was being held, made the new reform non-viable. Although there is an agreement about the existence of a crisis, this has not been the case about the analysis of its causes or solutions. At the present time, the government is not presenting a new reform proposal and is focusing on some decree to create a model of healthcare in rural zones, define financial conditions for the EPSes (health providers), update norms for membership in a healthcare system and regulate biotechnological drugs. Even though to date there have been no opinions, plus taking into account the previous analysis, it is very possible there will be much criticism from those who demand a structural change in the system.

\section{Keywords}

Health, Reform, Crisis 


\section{Introduction}

The 1993 reform caused a great "big bang" in the Colombian healthcare system, based on structure pluralism. Its goal was universal insurance and participation of public and private service with regulated competition.

From the moment healthcare changed, there were benefits for the population such as increased coverage, diminished individual spending, better insurance equity and a small increase in prevention and promotion [1].

The crisis which has been increasing is manifested by barriers to the healthcare service because of the act of being insured. This does not imply access to healthcare service and even less to high quality service [2], deleterious labor conditions and medical autonomy with inconformity and diminishing quality of attention from the healthcare professionals. Financial crisis—as assured by the Health Minister-is caused by increased affiliations to the subsidy scheme (those who don't contribute), increased money recovery from the state, the fact that although the benefit plan is equal, the value per capita paid by the general system of health (Social Security) to each EPS is not equal [3] and finally the lost of legitimacy in the system and leadership by the Ministry of Health.

In 2013 Congress received twelve reform projects, including a statutory law and an ordinary law from the Ministry of Health. Of the twelve projects only the statutory law that defines health as a fundamental right was approved. The ordinary law included four great proposals consisting of a unique fund which would administer the total resources of the health system "Salud Mia", one sole benefit plan for the entire population "Mi Plan", the "Gestores" (health services providers) which would be the organizations in charge of healthcare and assessing citizens in the use of the health systems and a new system for organizing the services offered by areas of sanitary conduct [4]. This total reform of the system was subject to strong criticism by the different opinion leaders and even though it was subject to various changes in searching for the necessary agreements, the critics continued and influenced directly or indirectly the rejection by Congress.

It is important to analyze from the most objective point of view and from the independence possible in academic work the different positions of the opinion leaders in order to understand correctly the reason for this failure and the next possible step to overcome the crisis.

\section{Methodology}

\subsection{Research Design}

The data were collected using the methodology Q adaptation that assigns quantitative values to the most frequent variables of opinion.

There was a search based on secondary sources (articles, views, newspapers, magazines, forum), in the period from June to December 2013. From there, different statements were extracted which give objective information about the propositions for health reform. Initially, a first evaluator made the extraction of a total of 74 statements given by six different actors.

\subsection{Sample}

For defining the sample a second evaluator performed a new revision of the different statements and after filtering repeated opinions of those which didn't give enough information about what was being evaluated, 30 statements were obtained.

\subsection{Procedure}

The opinion leaders were clustered in six different groups, health providers (physician and other personnel), civil society (associations and representatives of the society), media, government, insurance companies (for this study the name insurance companies represents EAPB and similar for a better comprehension by the reader) and users (patient associations).

Four different variables were created which evaluate objectively each one of the 30 statements in the sample. As such, the four variables for the analysis of each one of the statements were closeness to the government reform, partial critics to the reform, unity between members of the same point of view, and changes in opinion.

\subsection{Analysis of Data}

Each one of the variables was evaluated by the authors with a score from -3 to +3 . Afterwards, the significance 
is explained for each one of the variables.

- Closeness to the government reform:

- +3 Extremely agree with the reform

- -3 Extremely against the reform

- Partial critics of the reform:

- +3 Important critics of specific aspects of the reform

- -3 Scarce critics of specific aspects of the reform

- Unity among members of the same point of view:

- $\quad+3$ The different members of the same view expressed similar points of view

- -3 The different members of the same view expressed different points of view

- Changes in opinion:

- +3 Many changes of opinion about the reform

- 0 No changes in opinion about the reform

\section{Results}

A total of 40 different documents were analyzed which resulted in finding 74 statements of which 30 were selected. It was seen that the majority of the actors distanced themselves from the government, criticizing partial aspects of the reform with disagreements inside the representative's (or representatives'?) points of view with a tendency to polarize their opinions.

The users represented mainly by the patients associations distanced themselves from the start from the reform project presenting strong criticism and concern for the future of their health. The main concern is their access to specialists and the high cost of medicine. They questioned why the reform does not eliminate the assurance system pointing out that it is a barrier to the access of service. Due to the existence of different associations, there was no evident union between them but there was a homogeneous opinion about the reform. In general, there were not many changes of opinion among the associations during the debate (see Table 1).

Civil society, which corresponds to foundations, observatories, academy, and representatives of society in general, strongly disagrees with the reform, which focuses on the concerns about the quality of the services and the training of health professionals as well as the continuity of the assurance companies. It did not pronounce in a unified manner, but manifested similar concerns. In general there were no changes of opinion in civil society (see Table 2).

The health providers which pertain (or apply?) to physicians and other health professionals always disagreed with the reform as evidenced by the strong critical posture found and the disagreement with many of the proposals made by the government. In health personnel there was a strong cohesion against the reform by graduated physicians, residents and students that resulted in objections and letters directed to the Health Minister. There critics focused on the training of specialists by non-academic hospitals and the fact that the reform didn't improve the working conditions of the health staff. There were no changes in opinion, however. In general this group presented a unanimous opinion (see Table 3).

In the media there were diverse statements generating a median score because of the findings of critics and also closeness and support for the reform. Its critics manifested that partial changes would be made without any structural changes in the system and it was not focused on the needs of its users. There was no clear unity among the different media because of the diversity of statements and each type of media maintained its approaches during the time evaluated (see Table 4).

It was the government that proposed the reform in a way all its statements favored it, no evident critic was found except for some suggestions planned such as the suppression of controversial articles and specialist training by non-university hospitals. There is a clear unanimity within the government toward creating the reform so that changes of opinion were minimal (see Table 5).

The insurance companies defined as OPBPs (Organizations Providing Benefit Plans) presented diverse statements provoked by the association of the EPSes of the contributive regimen that moved from some criticism of certain aspects of the reform to a total disagreement with the project. Its critics focused on the changes of the functions of OPBPs which would change to their becoming "Gestoras" (providers) and the risks of cost increments. They agreed that the membership and money were to be government responsibility. Insurance association from the subsidized regimen and compensation funds show contrary opinions about this reform. Compared with the other opinion leaders this was the group with the most frequent changes in view points (see Table 6). 
Table 1. Statements from the users about the 2013 healthcare reform.

\begin{tabular}{|c|c|c|c|c|}
\hline Statements & $\begin{array}{l}\text { Closeness to the } \\
\text { government } \\
\text { reform }\end{array}$ & $\begin{array}{l}\text { Partial } \\
\text { critics of the } \\
\text { reform }\end{array}$ & $\begin{array}{l}\text { Unity among } \\
\text { members of the } \\
\text { same point of view }\end{array}$ & $\begin{array}{l}\text { Changes } \\
\text { in opinion }\end{array}$ \\
\hline $\begin{array}{l}\text { "Every patient receives aspirin and acetaminophen and } \\
\text { women with breast cancer will never arrive at an oncologist or } \\
\text { mastologist." [5] }\end{array}$ & -3 & 3 & 3 & 0 \\
\hline $\begin{array}{l}\text { "The drugs and technology out of POS, who will cover them } \\
\text { in the health system? This worries us because we will have a } \\
\text { backup in health." [6] }\end{array}$ & -2 & 2 & 2 & 0 \\
\hline $\begin{array}{l}\text { "This reform isn't adequate because EPSes continue; it is not } \\
\text { true they end.” [7] }\end{array}$ & -3 & 3 & -1 & 0 \\
\hline $\begin{array}{l}\text { "The health reform would favor EPSes that will be known as } \\
\text { Gestoras." [8] }\end{array}$ & 0 & 1 & -1 & 0 \\
\hline \multirow{2}{*}{$\begin{array}{l}\text { "The main problem in the reform project is that it does not } \\
\text { resolve the underlying question about what a Colombian } \\
\text { health model is." [9] }\end{array}$} & -1 & 1 & -1 & 1 \\
\hline & -9 & 10 & 2 & 1 \\
\hline
\end{tabular}

Source: author's own.

Table 2. Statements from the civil society about the healthcare reform of 2013.

\begin{tabular}{|c|c|c|c|c|}
\hline Statements & $\begin{array}{l}\text { Closeness to } \\
\text { the government } \\
\text { reform }\end{array}$ & $\begin{array}{l}\text { Partial } \\
\text { criticism of } \\
\text { the reform }\end{array}$ & $\begin{array}{l}\text { Unity among } \\
\text { members with the } \\
\text { same points of view }\end{array}$ & $\begin{array}{l}\text { Changes } \\
\text { in opinion }\end{array}$ \\
\hline $\begin{array}{l}\text { "We consider that opportunity for education can expand, but } \\
\text { without a social sense along with the physicians, quality } \\
\text { worsens and makes the specialists less professional, all of } \\
\text { which produce diminished attention in health." [10] }\end{array}$ & -3 & 3 & 3 & 2 \\
\hline $\begin{array}{l}\text { "There was no government capable of controlling EPS and } \\
\text { other viewers (why viewers?) and they ended up losing } \\
\text { control.” [11] }\end{array}$ & -3 & 3 & -1 & 0 \\
\hline $\begin{array}{l}\text { "The end of financial intermediation is not true because it is } \\
\text { clearly established that Gestoras (providers) of health } \\
\text { services, today EPSes, will go on affiliating, collecting money } \\
\text { and managing health resources." [12] }\end{array}$ & -3 & 3 & -1 & 0 \\
\hline \multirow[t]{2}{*}{$\begin{array}{l}\text { "EPSes have been masked, revived and had their names } \\
\text { changed to Gestoras (providers).” [13] }\end{array}$} & -3 & 3 & -2 & 0 \\
\hline & -12 & 12 & -1 & 2 \\
\hline
\end{tabular}

Source: author's own.

Table 3. Statements from the health providers about the healthcare reform of 2013.

\begin{tabular}{|c|c|c|c|c|}
\hline Statements & $\begin{array}{l}\text { Closeness to } \\
\text { the government } \\
\text { reform }\end{array}$ & $\begin{array}{l}\text { Partial } \\
\text { criticism of } \\
\text { the reform }\end{array}$ & $\begin{array}{l}\text { Unity among } \\
\text { members with the } \\
\text { same points of view }\end{array}$ & $\begin{array}{l}\text { Changes } \\
\text { in opinion }\end{array}$ \\
\hline "The reform is a detriment to quality in health attention." [14] & -3 & 3 & 1 & 1 \\
\hline $\begin{array}{l}\text { "We haven't understood that training specialists is not a } \\
\text { business but rather an investment in the country." [15] }\end{array}$ & -1 & 1 & 0 & 1 \\
\hline $\begin{array}{l}\text { "The reform talks about financial sustainability of the system } \\
\text { while reducing the income of the physicians." [16] }\end{array}$ & -3 & 3 & 3 & 0 \\
\hline $\begin{array}{l}\text { “Colombia needs general practitioners prepared to solve many } \\
\text { of the pathologies that today arrive at the specialists' offices } \\
\text { causing undue congestion.” [17] }\end{array}$ & 2 & 3 & 3 & 0 \\
\hline \multirow{2}{*}{$\begin{array}{l}\text { "The health reform currently in course in the House of } \\
\text { Representatives that intends for health institutions to train } \\
\text { specialists is not considered fair because academy is } \\
\text { considered a fundamental thing." [18] }\end{array}$} & -3 & 3 & 3 & 0 \\
\hline & -8 & 13 & 10 & 2 \\
\hline
\end{tabular}

Source: author's own. 
Table 4. Statements from the media about the healthcare reform of 2013.

\begin{tabular}{|c|c|c|c|c|}
\hline Statements & $\begin{array}{l}\text { Closeness to } \\
\text { the government } \\
\text { reform }\end{array}$ & $\begin{array}{l}\text { Partial } \\
\text { criticism of } \\
\text { the reform }\end{array}$ & $\begin{array}{l}\text { Unity among } \\
\text { members with the } \\
\text { same points of view }\end{array}$ & $\begin{array}{l}\text { Changes } \\
\text { in opinion }\end{array}$ \\
\hline $\begin{array}{l}\text { "Reform has strong and weak aspects that must be worked on } \\
\text { like any reform.” [19] }\end{array}$ & -1 & 1 & 0 & 1 \\
\hline $\begin{array}{l}\text { "It was urgent to 'sign in' into the operating room a drastic } \\
\text { reform to make it better and place it at the service of people.” } \\
\text { [20] }\end{array}$ & 2 & -1 & 2 & 2 \\
\hline $\begin{array}{l}\text { "Still without clarity about its significance, the proposal seems } \\
\text { a starting point far more just than the social emergency threats } \\
\text { or the failed attempt to update a charge from the extant } \\
\text { commission of regulation in health (CRES)" [21] }\end{array}$ & 2 & -1 & 1 & 2 \\
\hline \multirow{2}{*}{$\begin{array}{l}\text { "It is possible that the greater loss will be to waste the present } \\
\text { political opportunity for an underground change and keep, } \\
\text { instead, another transient arrangement that looks more toward } \\
\text { the past than toward the future." [22] }\end{array}$} & -2 & 2 & -2 & 1 \\
\hline & 1 & 1 & 1 & 6 \\
\hline
\end{tabular}

Source: author's own.

Table 5. Statements from the government about the healthcare reform of 2013.

\begin{tabular}{|c|c|c|c|c|}
\hline Statements & $\begin{array}{l}\text { Closeness to } \\
\text { the government } \\
\text { reform }\end{array}$ & $\begin{array}{l}\text { Partial } \\
\text { criticism of } \\
\text { the reform }\end{array}$ & $\begin{array}{l}\text { Unity among } \\
\text { members with the } \\
\text { same points of view }\end{array}$ & $\begin{array}{l}\text { Changes } \\
\text { in opinion }\end{array}$ \\
\hline $\begin{array}{l}\text { "The reform proposes an underground transformation } \\
\text { regarding its functioning and incentives.” [23] }\end{array}$ & 3 & -2 & 2 & 0 \\
\hline $\begin{array}{l}\text { "The rescue fund has a sole goal: save the hospitals. Those } \\
\text { who say otherwise are lying." [24] }\end{array}$ & 3 & -2 & 2 & 0 \\
\hline $\begin{array}{l}\text { "Some of the past reform articles are not subject to regulation } \\
\text { because they argue with the basic postulates of the current } \\
\text { model." [25] }\end{array}$ & 2 & -1 & 1 & 1 \\
\hline \multirow{2}{*}{$\begin{array}{l}\text { "Administrative ways are being sought to solve the gaps in } \\
\text { these statements after the unsuccessful transaction of the } \\
\text { ordinary law." [26] }\end{array}$} & 3 & -2 & 2 & 0 \\
\hline & 11 & -7 & 7 & 1 \\
\hline
\end{tabular}

Source: author's own.

Evaluating the different statements about the variable "Closeness to the government reform", there are tendencies of the majority of actors to be against the government proposal. It is evident that the tendency was nearly unanimous and the government was finally left alone (see Figure 1).

\section{Discussion}

Even though the reform project was led by the Health Ministry its failure shows a problem in one of the basic recommendations by WHO about the strengthening of the health system [35].

Each opinion leader expressed ideas about the convenience of the reform for his or her sector without mediating an analysis of the needs of the system as a whole and of making the users a priority. In other studies taking into account the system as a whole is recommended. It must be considered jointly by all agents involved in each health service [36].

The debate about reform has not considered the user as its center and the mechanisms to reduce inequities in the access to and results in health were also manifested in the study undertaken by the IDB [37].

Up to now Colombia maintains a segmented system even though intents have been made to search for mechanisms to increase social cohesion [38]. The evidence of studies shows that reducing certain dimensions of fragmentation may be much more politically viable and acceptable than others [39].

The most frequent spaces for debate about the reforms in Latin America have been the Parliament and in 
Table 6. Statements from the insurance companies about the healthcare reform of 2013.

\begin{tabular}{|c|c|c|c|c|}
\hline Statements & $\begin{array}{l}\text { Closeness to } \\
\text { the government } \\
\text { reform }\end{array}$ & $\begin{array}{l}\text { Partial } \\
\text { criticism of } \\
\text { the reform }\end{array}$ & $\begin{array}{l}\text { Unity among } \\
\text { members with the } \\
\text { same points of view }\end{array}$ & $\begin{array}{l}\text { Changes } \\
\text { in opinion }\end{array}$ \\
\hline $\begin{array}{l}\text { "The health reform proposed by the national government will } \\
\text { be disadvantageous to the state in the long run." [27] }\end{array}$ & -3 & 3 & -1 & 2 \\
\hline $\begin{array}{l}\text { "Health reform does not combat the underlying problems in } \\
\text { health and if approved the remedy would be worse than the } \\
\text { sickness." [28] }\end{array}$ & -2 & 2 & -2 & 2 \\
\hline $\begin{array}{l}\text { "The statutory and ordinary laws reform project presented by } \\
\text { the government toward the system reform for assuring } \\
\text { healthcare, far from controlling the costs of the system, will } \\
\text { raise them substantially." [29] }\end{array}$ & -2 & 2 & 1 & 2 \\
\hline $\begin{array}{l}\text { "The new health system would not improve the present } \\
\text { situation because it does not address the problems of the } \\
\text { patients' quality of services, opportunity nor } \\
\text { comprehensiveness." [30] }\end{array}$ & -3 & 3 & -1 & 3 \\
\hline $\begin{array}{l}\text { "The project transforms the EPSes which for } 20 \text { years have } \\
\text { struggled for its members in simple messengers who take and } \\
\text { bring documents, who take and bring messages.” [31] }\end{array}$ & -3 & 2 & -1 & 3 \\
\hline $\begin{array}{l}\text { "No serious and responsible private EPS could turn into a } \\
\text { 'Gestor' with the proposed rules.” [32] }\end{array}$ & -3 & 2 & 3 & 2 \\
\hline $\begin{array}{l}\text { "We agree for the state to assume total responsibility for } \\
\text { insuring, through direct affiliation, resource charges and their } \\
\text { administration and direct pay to the health providers, } \\
\text { functions that up to now have been carried out by the EPSes." } \\
\text { [33] }\end{array}$ & 3 & -3 & -3 & 3 \\
\hline \multirow{2}{*}{$\begin{array}{l}\text { "The EPSes have always assured that they are not interested } \\
\text { in managing the resources of the system and that they agree } \\
\text { for the government to take care of this task.” [34] }\end{array}$} & 3 & -2 & -1 & 3 \\
\hline & -10 & 9 & -5 & 20 \\
\hline
\end{tabular}

Source: author's own.

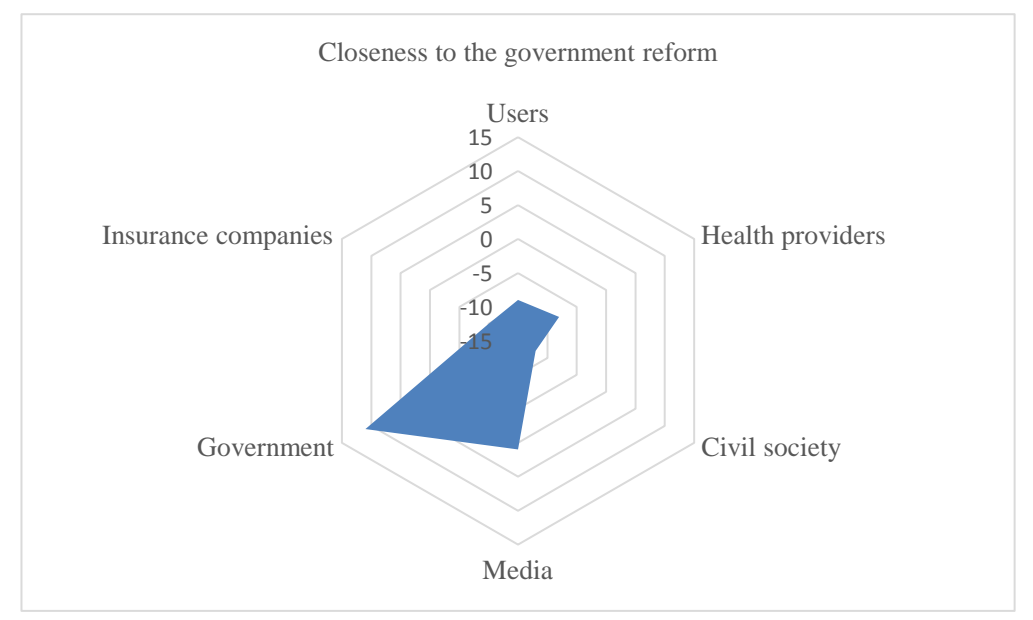

Figure 1. Closeness of the different health system groups regarding the proposal for a 2013 reform by the government.

some cases commissions created by the Health Ministry with the participation of different leaders [40]. The parliament does not seem the best space for seeking agreements among these leaders as was shown in the last reform attempt in Colombia.

As a different factor, the influence of presidential elections as experienced in Colombia at that time has to be considered. During the reform project release, the Ministry of Health declared that "the election campaign was a 
mortal event for health reform” [41]. Furthermore, some speakers referring to the reform assured that even though it was necessary to improve the system for patient attention in Colombia, it was necessary to delete this topic from any electoral debate [42]. The debate about the health system in Brazil was also affected by the elections in opinions such as: "For Lula's government, health was never a priority”, given by the health economist Aquiles Mendez of San Pablo University [43].

In the United States, it is considered that unless there is a change in the way campaigns are financed, there cannot be a reform in the health system [44].

\section{Conclusions}

There is an agreement among the leaders about the acknowledgement of health as a basic right and the publicprivate participation in healthcare services. The users, health services, individuals and civil society advocate for a system administered by the state, without profit and free of intermediation. The government maintains agencies of private management even though it changes their functions, and about this topic the insurance companies do not agree.

In the 30 statements evaluated in this study it was found that the great majority of leaders distanced themselves from the government by being critical about partial aspects of the reform, with disagreement among the leaders and with a tendency to polarize their opinion.

Because of the collapse in government reform projects, four new decrees have been proposed to create a model of health in rural and remote areas, define financial conditions for the EPSes, update norms for membership in healthcare systems and regulate biotechnological drugs. It is important to perform another analysis to evaluate whether or not these changes will be relevant and improve significantly to be a solution to the health crisis in Colombia.

\section{Ethical Considerations}

This study is considered as minimal risk in accordance with the Declaration of Helsinki because there is no intervention of humans or animals or personal data that may adversely affect confidentiality.

\section{Conflict of Interests}

There are no funds involved from any side. For both authors there are no conflicts of interest.

\section{References}

[1] Nuñez, J. and Zapata, J.G. (2012) La sostenibilidad financiera del sistema de salud Colombiano. http://www.fedesarrollo.org.co/wp-content/uploads/2011/08/La-sostenibilidad-financiera-del-Sistema-de-Salud-Colom biano-Libro-Sura-Final-20121.pdf

[2] Yepes, F.J. (2010) Luces y sombras de la reforma de la salud en Colombia. Ley 100 de 1993. Revista gerencia y políticas de salud, 9, 118-123. http://www.scielo.org.co/pdf/rgps/v9n18s1/v9n18s1a11.pdf

[3] Solano, M. (2013) Las tres razones de la crisis financiera del sector salud, según Gaviria. http://www.larepublica.co/economia/las-3-razones-de-la-crisis-financiera-del-sector-salud-seg\%C3\%BAn-gaviria_820 $\underline{86}$

[4] Gobierno de Colombia (2013) El gobierno te aclara más dudas sobre la reforma a la salud. http://www.urnadecristal.gov.co/gestion-gobierno/gobierno-aclara-dudas-sobre-reforma-salud

[5] RCN (2014) Médicos y pacientes rechazan la reforma en salud. http://www.noticiasrcn.com/nacional-pais/medicos-y-pacientes-rechazan-reforma-salud

[6] Dinero (2013) Reforma a la salud ignora a los pacientes. http://www.dinero.com/imprimir/170448

[7] Sepúlveda, F. (2013) Asociación de pacientes de Colombia tiene objeciones a la reforma a la salud. http://www.cmi.com.co/asociacion-de-pacientes-de-colombia-tiene-objeciones-a-la-reforma-a-la-salud/101729

[8] Caracol Radio (2013) Advierten cambios en Reforma a la salud que favorecerían a EPS. http://www.caracol.com.co/noticias/actualidad/advierten-cambios-en-reforma-a-la-salud-que-favorecerian-a-eps/20130 926/nota/1979939.aspx

[9] Semana (2013) Reforma a la salud: Una receta difícil de digerir. http://www.semana.com/nacion/articulo/una-receta-dificil-de-digerir/363370-3 
[10] El país (2013) Nuevo veto al proyecto reforma a la salud en Colombia. http://www.elpais.com.co/elpais/economia/noticias/nuevo-veto-proyecto-reforma-salud-colombia

[11] Semana (2013) La reforma del gobierno es solo un analgésico. http://www.semana.com/Imprimir/346484

[12] El Espectador (2013) Denuncian irregularidades en la reforma a la salud. http://www.elespectador.com/noticias/politica/denuncian-irregularidades-reforma-salud-articulo-413653

[13] RCN (2013) Médicos y pacientes rechazan reforma a la salud. http://www.noticiasrcn.com/tags/secretarios

[14] Redacción vivir (2013) Médicos convocan marcha en rechazo a reforma de la salud. http://www.elespectador.com/noticias/salud/medicos-convocan-marcha-rechazo-reforma-de-salud-articulo-454212

[15] Moreno, K. (2013) Formar más médicos, ¿una propuesta indecente? http://www.elespectador.com/noticias/salud/formar-mas-medicos-una-propuesta-indecente-articulo-452052

[16] El espectador (2013) Ministerio de Salud rechaza reducción de salarios a médicos. http://www.elespectador.com/noticias/salud/ministerio-de-salud-rechaza-reduccion-de-salarios-medic-articulo-454336

[17] Moreno, K. (2013) Formar más médicos, ¿una propuesta indecente? http://www.elespectador.com/noticias/salud/formar-mas-medicos-una-propuesta-indecente-articulo-452052

[18] De la cruz, L. (2013) Reforma a la salud es lesiva no solo para los médicos sino para todos los colombianos. http://www.elheraldo.co/local/reforma-la-salud-es-lesiva-no-solo-para-medicos-sino-para-todos-los-colombianos-1318 $\underline{42}$

[19] Argüello, A. (2013) El paro de los médicos es solo por la salud. http://www.eltiempo.com/archivo/documento/CMS-13147505

[20] El Heraldo (2013) Una reforma que entra a prueba. http://www.elheraldo.co/opinion/editorial/una-reforma-que-entra-a-prueba-114634

[21] Rossi, F. (2013) Intereses de congresistas amenazan reforma de la salud. http://www.unperiodico.unal.edu.co/dper/article/intereses-de-congresistas-amenazan-reforma-de-la-salud.html

[22] Franco, S. (2013) Reforma en salud: ¿el parto de los montes? http://www.razonpublica.com/index.php/politica-y-gobierno-temas-27/3610-reforma-en-salud-iel-parto-de-los-montes. $\underline{\mathrm{html}}$

[23] Gobierno de Colombia (2013) El gobierno te aclara más dudas sobre la reforma a la salud. http://www.urnadecristal.gov.co/gestion-gobierno/gobierno-aclara-dudas-sobre-reforma-salud

[24] Gobierno de Colombia (2013) El gobierno te aclara más dudas sobre la reforma a la salud. http://www.urnadecristal.gov.co/gestion-gobierno/gobierno-aclara-dudas-sobre-reforma-salud

[25] Gobierno de Colombia (2013) Abecé de la Reforma a la Salud. http://www.urnadecristal.gov.co/gestion-gobierno/abec-de-reforma-a-salud

[26] Estilo de vida (2013) El 80\% de la reforma de la salud ya está hecho: Minsalud. http://www.eltiempo.com/estilo-de-vida/salud/alejandro-gaviria-habla-sobre-reforma-de-la-salud/14081979

[27] El Universal (2013) Reforma a la salud será desventajosa para el Estado a largo plazo: Acemi. http://www.eluniversal.com.co/cartagena/nacional/reforma-la-salud-sera-desventajosa-para-el-estado-largo-plazo-acem i-110076

[28] Terra noticias (2013) Reforma a la salud no combate corrupción: Acemi. http://noticias.terra.com.co/bogota/reforma-a-la-salud-no-combate-de-fondo-la-corrupcion-acemi,d1d2c481e288d310V gnVCM5000009ccceb0aRCRD.html

[29] Azuero, F. (2013) La reforma en el sistema de salud: El papel de las gestoras. http://franciscoazuero.blogspot.com/2013/05/la-reforma-en-el-sistema-de-salud-el.html

[30] Arias, J. (2013) Lo que viene en salud será malo para el país. http://www.elpais.com.co/elpais/economia/noticias/viene-salud-sera-malo-para-pais-presidente-acemi

[31] Correa, J. (2013) Minsalud y acemi chocan por refoma. http://www.eltiempo.com/archivo/documento-2013/DR-93533

[32] Acemi (2013) Las EPS afiliadas a ACEMI, no encuentran condiciones para ser “Gestoras de salud”. https://organizacionmisalud.com.co/wp-content/files_mf/13721876471371313706ComunicadoAcemiFOROANDIJUN IO7.pdf

[33] Acemi (2013) Amenazas sobre la sostenibilidad del Sistema de Salud. Revista Conexxión, 2, 24-32.

[34] Acemi (2013) La reforma a la salud no resuelve los verdaderos problemas que padecen los usuarios. http://www.acemi.org.co/images/actualidad/acemi_informa/2013/acemi_comunicado-08-ago-2013.pdf

[35] World Health Organization (2010) Key Components of a Well-Functioning Health System. 
http://www.who.int/healthsystems/EN_HSSkeycomponents.pdf?ua=1

[36] Avellaneda, M. (2008) Incompatibilidades y complementariedades entre la lógica económica y médica en el actual sistema de salud.Ph.D. Defensa de tesis, Bogotá, Escuela de Gobierno Alberto Lleras Camargo, Universidad de los Andes, Bogotá.

[37] IDB (2014) Comparative Review of Health System Integration in Selected Countries in Latin America. http://publications.iadb.org/bitstream/handle/11319/6024/Technical\%20Note\%20585-\%20Health\%20System\%20Frag mentation.pdf?sequence $=1$

[38] Osorio, M. (2014) Perspectiva del sistema de salud Colombiano. http://www.consultorsalud.com/attachments/article/0/Asi\%20vamos\%20en\%20salud\%20informe\%20anual.pdf

[39] IDB (2014) Comparative Review of Health System Integration in Selected Countries in Latin America. http://publications.iadb.org/bitstream/handle/11319/6024/Technical\%20Note\%20585-\%20Health\%20System\%20Frag mentation.pdf?sequence $=1$

[40] Arriagada, I., Aranda, V. and Miranda, F. (2005) Políticas y programas de salud en América Latina. Problemas y propuestas. http://www.cepal.org/publicaciones/xml/7/23777/sps114_lcl2450.pdf

[41] W Radio (2014) Campaña electoral fue mortal para la reforma a la salud, dice Minsalud. http://www.wradio.com.co/noticias/actualidad/campana-electoral-fue-mortal-para-la-reforma-a-la-salud-dice-minsalud/ 20140605/nota/2259350.aspx

[42] RCN (2014) Piden aplazar Reforma a la salud para después de Elecciones presidenciales. http://www.rcnradio.com/noticias/piden-aplazar-reforma-la-salud-para-despues-de-elecciones-presidenciales-121913

[43] Caulyt, F. (2014) Brasil mejora, pero no lo suficiente. http://www.dw.de/brasil-mejora-pero-no-lo-suficiente/a-17973425

[44] Navarro, V. (2008) The Politics of Health Care Reforms in US Presidential Elections. http://www.vnavarro.org/wp-content/uploads/2008/12/politics-of-health-care-reforms-in-us-presidential-elections-ijhsvol-38-no-4-2008.pdf 
Scientific Research Publishing (SCIRP) is one of the largest Open Access journal publishers. It is currently publishing more than 200 open access, online, peer-reviewed journals covering a wide range of academic disciplines. SCIRP serves the worldwide academic communities and contributes to the progress and application of science with its publication.

Other selected journals from SCIRP are listed as below. Submit your manuscript to us via either submit@scirp.org or Online Submission Portal.
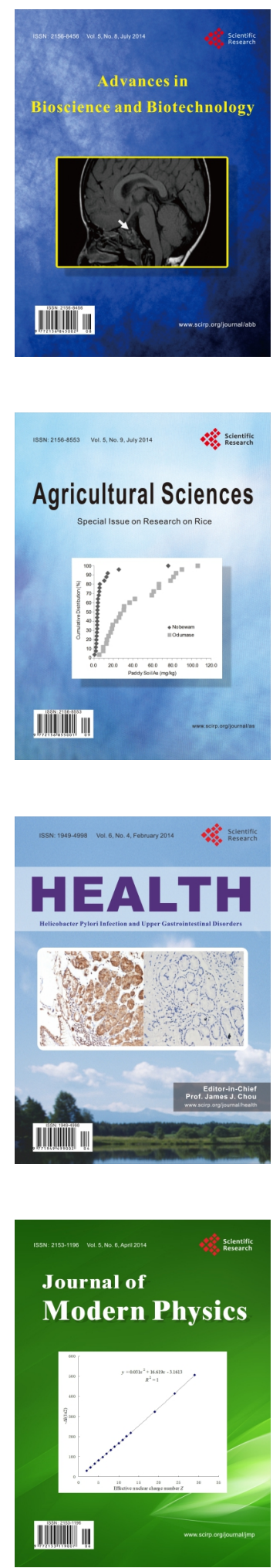
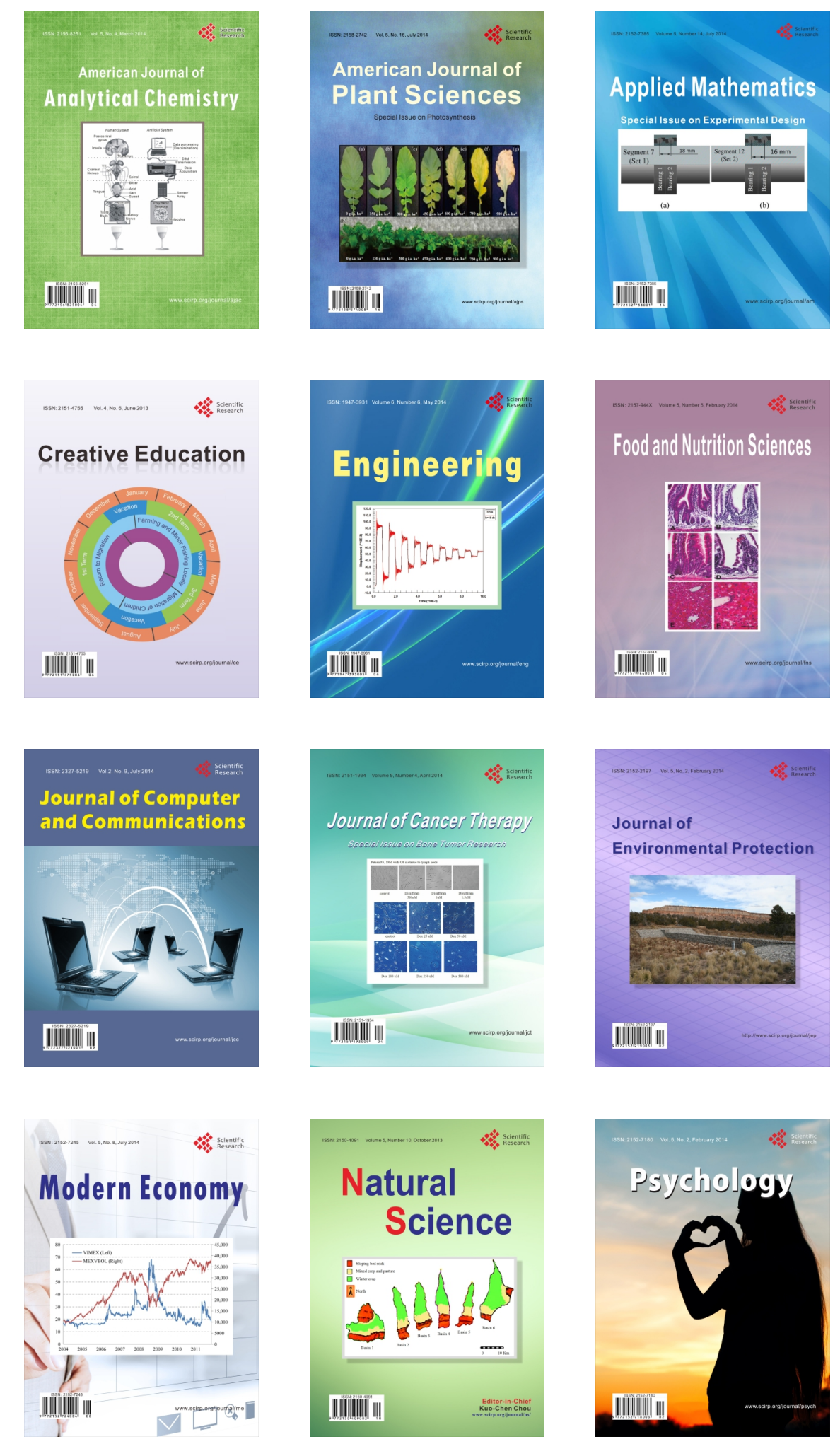